
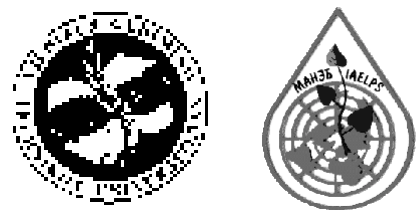

\title{
INFLUENCE OF UNFAVOURABLE ENVIRONMENTAL FACTORS UPON HEALTH OF WORKERS AND CORRECTION OF RESULTANT ALTERATIONS
}

\author{
Dalia Stasytytė-Bunevičiené ${ }^{1}$, Algirdas Juozulynas ${ }^{2}$, Antanas Jurgelėnas ${ }^{2}$ \\ ${ }^{1}$ Center of Physical Medicine and Rehabilitation of Vilnius University Hospital „Santariškiu klinikos“", \\ Santariškiu g. 2, LT-08406 Vilnius, Lithuania, Phone: 2340205 (home), E-mail: stasytyte@mailcity.com \\ ${ }^{2}$ Institute of Clinical and Experimental Medicine of Vilnius University, Žygimantu 9, Vilnius, Lithuania, \\ Phone: 2624120,E-mail: algirdas.juozulynas@ekmi.vu.lt
}

Received 25 Feb 2005; accepted 15 Mar 2005

\begin{abstract}
Intensified formation of free radicals is one of the most important unfavourable consequences of factors of industry acting upon human organism. Under physiological conditions, antioxidative system preserves from harmful influence of free radicals. To avoid a disturbing influence of oxidative stress upon the processes of human homeosthasis, additional quantities of antioxidants are indispensable. Dynamics of alterations of markers of oxidative stress caused by unfavourable industrial factors of metal processing (chemical agents, vibration, noise) under impact of native biomodulators were studied using native pollen. The programme was performed on 50 workers of metal processing, 9 males and 41 female, who used pollen during a period of 1 month. Control group consisted of 57 persons, 10 males and 47 females living and working under the same conditions. Blood tests (diene conjugates, malonic dialdehyde and katalase) using spectrophotometric methodology were studied before and after the course of treatment. After the treatment, contents of metabolites of lipid peroxidation, diene conjugates and malonic dialdehyde in blood serum essentially reduced. Activity of catalase decreased significantly in blood serum of males and regularly smoking females. In conclusion, presented data demonstrate antioxidative efficiency of native pollen and suggest more often applying of native biomodulators in cases with alterated processes of homeosthasis under impact of unfavourable environmental factors.
\end{abstract}

Keywords: environmental factors, metal processing, native biomodulators, oxidative stress, pollen, smoking.

\section{Introduction}

Problems of health of people living and working under impact of contemporary harmul factors of an industrial environment require nonstandard methods of prophylaxis, rehabilitation and treatment. Against a background of intensive chemical polluteness and of physical factors - noise, vibration, elec-tromagnetic alterations and others, usual pharmacological agents quite often prove to be not very efficacious, while medicines become an additional source of allergens. The processes of a pathogenetic and ethiotropic treatment become distorted by contamination of exogenous origin which affects the human organism. Interaction of drugs with the contaminants that are present in organism and have got into it from its surroundings and with their metabolites has not been studied much, yet constituting a problem of great importance. Today quite a number of complica- tions of chemiotherapy are related to the intricate enzymic processes not characteristic of human organism under ordinary conditions. The essence of these processes consists in pathologic peroxidation reactions wich are initiated by a great number of organic and inorganic compounds of industrial occurrence and during which free radicals are formed, joining the chain of vital processes of the cell, changing its electric potential, disturbing permeability of membranes and exhausting native antioxidative systems [1]. All these complicated events of oxidative stress disturb homeosthasis of human organism, suppress its vitally important functions, weaken its general and specific immunity. The action of nonmedicamentous measures of prophylaxis and treatment, application of which is based on longterm observations, has been explained of late decades by the development of complex of positive changes in homeosthasis under the effect of those measures [2]. 
Industrial pollution is not a single and the only exogenous source of free radicals in humans working at industrial enterprices. Some factors of the mode of life of those workers, especially tobacco smokers, also play a great role in the intensified processes of free radicals and are well-known satelites of people working under impact of harmful factors of an industrial environment [3-5]. Much additional information corroborating the hazards of smoking come from the WHO studies, the Kaunas-Rotterdam Intervention Study (KRIS) and Monitoring of Trends and Determinants in Cardiovascular Diseases (MONICA) among them [6]. As S. Domarkiene, A. Tamošiūnas, R. Reklaitienè (2003) reported, during the last 19 years the prevalence of smoking in middleaged population of Kaunas has increased among women, by $7,2 \%$, and has not changed significantly among men [7]. Some epidemiological studies of the last period, and those from Lithuania among them, announced significant decrease in prevalence of smoking among men related to their higher education, while this tendency among people who obtained secondary or lower education has not been found [8-10]. As some groups of researchers from Sweeden, Japan, United Kingdom et al. have announced, people working under impact of harmful factors of metal processing consist of a group of high risk to become ill with cardiovascular diseases and cancer, and this probability for smokers may be increased 2-3 times. R. Petrauskaitè Everatt (2000) presenting data of retrospective case control study, found a relative dependence of risk to become ill with lung cancer upon occupation (workers of metal processing among them), period of working under impact of hazardous professional factors and smoking [11].

An object of nonmedicamentous measures and methods acting upon the organism is vegetative nervous system which can be influenced by native chemical compounds, physical and physiological means. The chief thing is their merit of moderately regulating of the processes going on in the organism - stimmulation, inhibition, and maintaining balance among them. Nonmedicamentous measures promote cleaning processes in eliminating unnecessary matherials of endogenous and exogenous origin. Modern science has already recognized native worldwide substances and products of vital activities of organisms as having the properties of biomodulation [12]. Among them, bee products, medicinal herbs and other native or preformed native substances standing out for such properties in Lithuania and foreign countries similar with respect to geographical conditions [13, 14].

In recent years, bee products attract an everincreasing attention of physicians, scientists and public. Pollen, as one of bee products, easily available and has been used long since because of its broad spectrum of action for the purposes of prophylaxis and treatment in Lithuania as well as in Latvia, Byelorussia as close countries with respect to climate and flora [15-16].

Biomodulative effects of pollen on different links of human homeosthasis were studied estimating alter- ations of clinical biochemical and immunological tests and indices reflecting processes of lipid peroxidation and antioxidative system activity. Considerable positive alterations established after treatment - diminution of immunodefficiency, reduced concentrations of lipid peroxidation metabolites, positive changes of biochemical blood tests - substantiate recommendations for more extensive usage of pollen as an effective biomodulative complex for rehabilitation and sthrengthening of the population health $[17,18]$.

The present study aimed to estimate and evaluate the indices of chemical agents of metal processing, noise and vibration at the workplaces of workers, and evaluate alterations of markers of oxidative stress as well as dynamics of those indices under impact of native pollen.

\section{Material and methods}

The object of investigation - practically healthy middle-aged workers (34-50 years old) working under the same harmful conditions of metal processing, indices reflecting their status of health and factors of chemical pollution, noise and vibration at their workplaces. All the persons who took part in the study were asked about their smoking habits according to a standard questionaire [10].

The programme was performed on 50 workers of metal processing, 9 males and 41 female, working under impact of the same industrial agents for more than 10 years, during a cold season of the year. Before administering bee products, a special purpose history as to hypersensivity to them, was taken additionally. All of them used native pollen $10 \mathrm{~g}$ per day during a period of 1 month. A control group consisted of 57 persons, 10 males and 47 females, living and working under the same conditions.

Blood tests (diene conjugates, malonic dialdehyde and katalase) using spectrophotometric methodology were studied before and after the course of correction.

Contamination of an industrial environment during the investigation was evaluated by ascertainment of 8 chemical substances in the air of industrial premisses using gas chromatography (nitrogen oxides, carbon monoxide, welding aerosol, metal dust, trichloroethylene, trietanolamine, sodium nitrite, freone 113). Noise, general and local vibration were evaluated by a standard methodology. Measurements $(n=24)$ of all the factors of professional risk were performed by the specialists of engineering staff at the Laboratory of Labour Protection of the enterprise. Results of the investigation were evaluated comparing with the highest permissible concentrations and levels in accordance with their validity at the period of investigation Lietuvos Higienos Norma (1993), by PC. The results of blood tests were analysed in relation to sex and smoking habits before and after the course, among the participants and workers of the control group, by PC, using package of programmes SPSS Version 11. 


\section{Results and discussion}

During the process of statistical analysis of the data reflecting industrial contamination with chemical substances, it was found that indices of contamination of industrial premisses with trichloroethylene exceeded the permissible index up to 2,9 times, contamination with trietanolamine - 1,3 times, contamination with sodium nitrite - less than 2 times. Indices of contamination with metal dust and sodium nitrite, and the level of noise exceeded the permissible indices by more than $75 \%$ of all the measurements (Fig)



Indices of evaluated professional factors exceeding permissible indices (in percents) at workplaces

All the persons who received pollen felt well during the course of treatment. After the treatment, $46 \%$ of participants pointed out to a considerable improvement of a general condition, increase in work capacity, $62 \%$ of all the participants had improved their appetite. $24 \%$ of persons, who had constipation troubles, pointed to normalized evacuation of their bowels.

After the correction, in blood serum of the participants, both males and females, concentration of metabolites of lipid peroxidation significantly reduced: concentration of diene conjugates - by 33-39\%, concentration of malonic dialdehyde - by $36-28 \%$. Activity of catalase prominently reduced in blood serum of males, by $35 \%(p<0,05)$. Comparing the indices of the workers from the main and control groups after the course, significant differencies of concentration of metabolites of lipid peroxidation were found: under the effect of pollen lower concentrations by $43-$ $45 \%$ in blood serum of both males and females were obtained $(p<0,05)$. Activity of catalase in blood serum of males from the main group was found to be significantly lower, comparing with the index of males from the control group (by $36 \% ; p<0,05$ ). In blood serum of regularly smoking persons $(n=26)$ concentrations of diene conjugates and malonic dialdehyde after the course reduced by $51 \%$ and $49 \%$. As it was found, activity of catalase in blood serum of regularly smoking females (who used no less than 1 cigarette per day) reduced essentially - by $53 \%$ ( $p=$ 0,0001).
In general, examined workers of metal processing during the period of observation were exposed to a complex of factors of professional risk significantly exceeding permissible indices (including sodium nitrite and trichloroethylene, well-known for their genotoxic effects). Under the effect of native biomodulators of pollen, significant positive changes restituting the balance among the processes of lipid peroxidation and activity of antioxidative system were obtained. The most important positive processes in blood serum of smoking workers were found. The presented data demonstrate antioxidative efficiency of native pollen and suggest more frequent application of native biomodulators in cases with alterated processes of homeosthasis under the impact of unfavourable environmental factors. During the investigation, no casess of allergic reactions or hypersensivity were observed. Keeping in mind possible allergy, before correction it may be suggested to pay great attention to a special purpose history as to hypersensivity to bee-products.

\section{Conclusions}

- During the period of investigation, examined workers were working under the impact of a complex of unfavourable industrial agents.

- Under the effect of native biomodulators of pollen, possitive changes of indices of oxidative stress were found: significantly reduced amounts of metabolites of lipid peroxidation in blood serum of males and females, and decreased activity of catalase in blood serum of males.

- After the course of pollen, activity of catalase significantly decreased in blood serum of regularly smoking females.

- Native pollen are effective biomodulative agents correcting alterations of the balance among lipid peroxidation and activity of antioxidative system caused by oxidative stress.

- As an effective biomodulator, native pollen may be more often recommended for people working under harmful conditions. Before the administration, purpose history as to hypersensivity or allergy to beeproducts must be taken.

\section{References}

1. Sies, H. Oxidative Stress. American Journal of Medicine, 91(3C), 1997, p 31- 37.

2. Bendick, A. Physiological role of antioksidants in the immune system. Yournal of Dairy Science, Vol 76, No 9, 1993, p 2789-2794.

3. Moffatt S.; Phillimore P.; Hudson E., et al. "Impact? What impact?" Epidemiological research findings in the public domain: a case study from north-east England. Social Science \& Medicine, No 51, 2000, p 1755-1769.

4. Douglas, I.; Hodgson, R., Lawson N. Industry, environment and health through 200 years in Manchester. Ecological Economics, No 41, 2002, p 235- 255.

5. Heloma, A.; Kahkonen, E.; Kaleva, S., et al. Smoking and 
exposure to tobacco smoke at medium-sized and large-scale workplaces. American Journal of Industrial Medicine, Vol 37, No 2, 2000, p 214-220.

6. The World Health Report 2002. Reducing risks, promoting healthy life. WHO, Geneva, 2002, p 7-26.

7. Domarkienè, S.; Tamošiūnas, A.; Rèklaitienè, R., et al. Trends in main cardiovascular risk factors among middleaged Kaunas population between 1983 and 2002. Medicina, Vol 39, No 12, 2003, p 1193-1199.

8. Tobacco Control Country Profiles. The 11th World Conference on Tobacco or Health. Atlanta (GA): American Cancer Society, 2000, p 3.

9. Health 21. Health for all in the 21 st century. European Health for All Series, No 6. Regional office for Europe, World Health Organisation, Copenhagen, 1998.

10. Tamošiūnas, A. Behavioral Risk Factors. Prevalence, trends, prognostic impacts on morbidity and mortality from different cause. Acad. dissert. Kaunas, 1997, p 3-16 (in Lithuanian).

11. Petrauskaite Everatt, R. Trends of dynamics of mortality from lung cancer in Lithuania and evaluation of unfavourable factors among population of high risk. Acad. dissert. Vilnius, 2000, p 2-17 (in Lithuanian).

12. Sun, G. Free radicals, antioxidant enzymes and carcinogenesis. Free Radical Biology Medicine, No 8, 1998, p 583-590.

13. Milašienè, V.; Mickevičius, J.; Keršienè, R. ir kt. Influence of bee-products under patient's immune and antioxidative systems during stomach and bowel cancer treated by surgical methods. Medicina, No 32, 1996, p 189-195 (in Lithuanian).

14. Stasytytė-Bunevičienè D.; Kemeklienè R.; Kazbarienè, B., et al. Correction of alterations of immune functions and lipid peroxidation by pollen and herbs. In: Problems of Prophylaxis of Cancer. Ed. by E. Moncevičiūtè-Eringienè. Science and Arts of Lithuania, Book 33. Vilnius, 2001, p 176-189.

15. Stasytytè-Bunevičienè, D.; Gendrolis, A. Influence of Native Biomodulators of Pollen upon Homeostatic Indices of Humans. In: Matherials of the 1-rst German Bee-Products and Apitherapy Congress with International Participation. Holiday in Passau, Germany. March 22-24, 2002. Passau 2002. p 55.

16. Млявый, В. П.; Иванова, О. Л.; Карпенко, О. А. Пчелотерапия синдромального комплекса. Апитерапия сегодня. Рязань, 2002, с. 136-137 (in Russian).

17. Stasytytė-Bunevičienè, D. Native biomodulators and vitamines during process of convalescention: comparable studies of their influence upon lipid peroxidation and status of antioxidative system. Sveikatos mokslai, No 7, 2002, p. 4648 (in Lithuanian).

18. Stasytytė-Bunevičienè, D.; Bunevičius J. Correction of Alterated Indices of Human Homeosthasis by Native Biomodulators of Pollen: Direct and Remote Results. In: Materials of the 5-th Conference of Military Medicine. Kaunas, December 5-6, 2002. Kaunas, 2002, p. 19.

\title{
NEPALANKIU APLINKOS VEIKSNIŲ POVEIKIS DARBUOTOJŲ SVEIKATAI IR DE்L TO KYLANČIŲ ALTERACIJŲ KOREGAVIMAS
}

\author{
D. Stasytytè-Bunevičienė, A. Juozulynas, A. Jurgelẻnas
}

\section{$\mathrm{S}$ a n tra u k a}

Nepalankių išorinès aplinkos veiksnių poveikis žmogaus organizmui ryškiausiai pasireiškia padidejusiu laisvujų deguonies radikalų sintezès intensyvumu. Iprastinèmis fiziologinėmis sąlygomis nuo žalingo laisvujų radikalų poveikio ląsteles apsaugo antioksidacinė sistema. Oksidacinio streso metu šiu procesų sukeliamiems negatyviems homeostazės rodikliu pokyčiams atkurti reikalingi papildomi antioksidantų kiekiai. Oksidacinio streso žymenų alteracijų, atsiradusių veikiant nepalankiems žmonių sveikatai pramoniniams veiksniams metalo apdorojimo procesuose (cheminės medžiagos, vibracija, triukšmas), dinamika, šių pokyčiu atkūrimo natūraliais biomoduliatoriais galimybès buvo vertinamos, naudojant bičių suneštas žiedadulkes. Programoje dalyvavo 50 pramonės i̇monès darbuotojų, dirbančių metalo apdorojimo procesuose -9 vyrai ir 41 moteris. Jie vartojo žiedadulkes kasdien 30 dienų. Kontrolinę grupę sudare 57 asmenys - 10 vyrų ir 47 moterys - gyvenantys ir dirbantys tokiomis pačiomis sąlygomis. Visiems asmenims prieš korekciją ir po 30 dienų buvo tiriami dviejų lipidų peroksidacijos metabolitų - dijenų konjugatų ir malono dialdehido kiekiai kraujo serume, antioksidacinio fermento katalazès aktyvumas. Tyrimai atlikti pagal spektrofotometrines metodikas. Po korekcijos nustatyti lipidų peroksidacijos procesų pokyčiai. Jie pasireiškè esminiu dijenų konjugatų ir malono dialdehido kiekių sumažejjimu tirtų asmenų kraujo serume. Antioksidacinio fermento katalazės aktyvumas reikšmingai sumažèjo tiriamosios grupės vyrų bei reguliariai rūkančių moterų kraujo serume. Tyrimo duomenys patvirtina antioksidacini bičių suneštų žiedadulkių efektyvumą. Rekomenduojama plačiau taikyti žiedadulkes kaip efektyvius biomoduliatorius, kurie gali sèkmingai koreguoti nepalankių aplinkos veiksnių sukeltus homeostazès pokyčius.

Dalia STASYTYTE்-BUNEVIČIENĖ. Dr (medical sciences), physician, Center of Physical Medicine and Rehabilitation of Vilnius University Hospital "Santariškiu klinikos".

Publications: author of 82 scientific publications. Research interests: alterations of indices reflecting human homeosthasis under impact of anthropogenous contamination and their correction using traditional and nonmedicamental methods, evaluation of efficacy of different methods. 
D. Stasytyté-Bunevičiene et al / Journal of Environmental Engineering and Landscape Management - 2005, Vol XIII, No 2, 141a-145a 145a

Algirdas JUOZULYNAS. Dr Habil (medical sciences), Prof, Institute of Clinical and Experimental Medicine of Vilnius University.

Publications: author of 228 scientific publications. Research interests: environmental protection, public health and prophylaxis.

Antanas JURGELÉNAS, Dr (biomedical sciences), Institute of Clinical and Experimental Medicine of Vilnius University. Publications: author of 24 scientific publications. Research interests: public health, theory of system, sustainable development. 